INFORMASI: Kajian Ilmu Komunikasi - ISSN (p) o126-o650; ISSN (e) 2502-3837

Vol. 48, No. 1 (2018), pp.139-152. doi: http://dx.doi.org/10.21831/informasi.v48i1.18620

\title{
KONSTRUKSI MEDIA DALAM PEMBERITAAN KONTRA TERORISME DI INDONESIA
}

\author{
Mubarok \\ mubarok@unissula.ac.id \\ Diah Wulandari \\ diah.wulandari@unissula.ac.id \\ Program Studi Ilmu Komunikasi \\ Universitas Islam Sultan Agung Semarang
}

\begin{abstract}
In various parts of the world terror events and the perpetrators became news material of interest to the media. The news about terrorism is also a part of the construction process. It is no less important in the effort to eliminate terrorism in Indonesia is a counterterrorism movement that emphasizes aspects of prevention rather than the act of terror. This study aims to see how the mass media in Indonesia to construct counterterrorism messages. The paradigm of this research is a constructivist paradigm that differs from other paradigms in epistimology, ontology, axiology, and methodology. Framing analysis, as an analytical technique in this study, belongs to the paradigm of constructivism. This research uses framing analysis method of Pan and Kosicki. The results showed Framing Detik.com emphasized the news hardnews in the news of terrorism during the year 2017. Metrotvnews.com put forward the testimony of the news with resource persons manta perpetrators of terror as a counterterrorism effort. Kompas.com put forward the official source of the police and BNPT in constructing the message kontraterosime. Viva.co.id praised the police performance and emphasized the aspect of lone wolf (single terrorist) as the exception of structured terrorism handling.
\end{abstract}

\begin{abstract}
Abstrak
Peristiwa teror dan pelakunya menjadi bahan berita yang menarik bagi media. Pemberitaan tentang terorisme juga merupakan bagian yang tidak terlepas dari proses konstruksi. Hal yang tidak kalah penting dalam upaya menghapus terorisme di Indonesia adalah gerakan kontraterorisme yang menekankan aspek pencegahan daripada penindakan terror. Penelitian ini bertujuan untuk melihat bagaimana media massa di Indonesia melakukan konstruksi pesan kontraterorisme. Paradigma penelitian ini adalah paradigma konstruktivis yang berbeda dengan paradigma lain dalam hal epistimologi, ontology, aksiologi, dan metodologi. Analisis framing, sebagai teknik analisis dalam penelitian ini, termasuk ke dalam paradigm konstruktivisme. Penelitianini menggunakan metode analisis framing Pan dan Kosicki. Hasil penelitian menunjukkan Framing Detik.com menekankan pemberitaan hardnews dalam pemberitaan terorisme
\end{abstract}


selama tahun 2017. Metrotvnews.com mengedepankan testimony pemberitaan dengan narasumber manta pelaku terror sebagai upaya kontraterorisme. Kompas.com mengedepankan sumber resmi dari kepolisian dan BNPT dalam mengkonstruksi pesan kontraterosime. Viva.co.id memuji kinerja kepolisian dan menekankan aspek lone wolf (teroris tunggal) sebagai pengecualian penangan terorisme yang terstruktur.

Keywords: Terrorism, Media, Construction, News.

\section{PENDAHULUAN}

Terorisme menjadi salah satu tema utama pemberitaan media massa di berbagai belahan dunia. Peristiwa teror seperti peledakan bom, penyerangan aparat, penyerangan tempat ibadah, sabotase, penangkapan para pelaku terror menjadi bahan berita yang menarik bagi media. Terorisme dan media memiliki kaitan erat dalam hubungan simbiosis mutualis meski tidak bersifatlangsung. Media membutuhkan bahan berita yang menarik khalayak, di sisi lain para pelaku teror membutuhkan publisitas untuk menunjukkan eksistensi atau menyebarkan alasan ideologis dibalik aksi teror yang mereka lakukan. Teori agenda setting dan framing bisa menjelaskan bagaimana kaitan antara terorisme dan media. Dalam agenda setting semakin besar perhatian media terhadap suatu fenomena maka semakin besar perhatian masyarakat terhadap fenomena tersebut. Framing menjelaskan bagaimana media menyajikan suatu berita akan mempengaruhi bagaimana audiens mengartikan dan memahami fenomena yang diberitakan.

Relasi antara kepentingan propaganda teroris dengan kepentingan nilai berita dari media bertemu dalam formulasi teks yang lahir. Hubungan simbiosis antara media dan teroris dalam formulasi teks nampak dalam pemberitaan yang menjadikan topik tersebut sebagai agenda utama. Media membutuhkan isu terorisme sebagai berita utama, sementara teroris berusaha untuk menjadi agenda utama dari pemberitaan media. Bertemunya dua kepentingan antara teroris dan media memberikan pengaruh bagi persepsi publik dan reaksi pemerintah dalam menangani terorisme.

Media sesungguhnya berada di tengah realitas sosial yang sarat dengan berbagai kepentingan, konflik, dan fakta yang kompleks dan beragam. Isi media tidak hadir begitu saja melainkan melalui mekanisme tarik menarik kepentingan internal dan eksternal yang kuat. Apa yang tersaji di media bukanlah realita yang sesungguhnya melainkan formulasi kerja redaksional yang menghadirkan kembali realitas dalam wajah yang lain. Media melalui formulasi tersebut menghadirkan realitas baru yang telah mengalami penambahan, pengurangan, perbaikan, penghapusan atau bahkan distorsi dari realitas sesungguhnya. Isi media sarat dengan berbagai kepentingan yang melingkupinya.

Beragam kepentingan tersebut yang kemudian membentuk bagaimana realitas dihadirkan dalam konten media. Kepentingan ideologis, ekonomi, politik, sosial, budaya dan kontestasi kepentingan lainnya akan sangat menentukan bagaimana corak dan warna isi media. Sebuah fakta yang sama bisa dimaknai dan dihadirkan berbeda kepada audiens sesuai dengan tarik uluryang melingkupinya. Di sini nampak bahwa media merupakan agen pendefinisi realitas yang secara aktif menentukan definisi terhadap suatu realitas tertentu. Siapa yang disebut jahat, baik, curang, diberi label positif dan negative merupakan hasil formulasi redaksional yang dipengaruhi beragam kepentingan. Selain aspek ekonomi dan politik yang mempengaruhi isi media, aspek ideologis juga memegang peran penting dalam pendefinisian realitas (Littlejohn, 2008).

Konten media adalah pertarungan dari ideology, kepentingan ekonomi, kepentingan social, rutinitas media dan kemampuan kinerja dari awak media. Artinya kompleksitas formulasi isi media tidak bisa disederhanakan dengan hanya melihat dampak dari isi media.. Gans dan Gitlin mengkategorikan beberapa 
perspektif teoritis yang digunakan untuk melihat isi media. Pertama adalah isi media merefleksikan realitas tanpa distorsi atau hanya ada sedikit distorsi dari realitas, kedua isi media dipengaruhi oleh sosialisasi dan sikap dari pekerja media. Ketiga, isi media dipengaruhi rutinitas kerjanya, keempat isi dipengaruhi kekuatan institusi lain di luar media, dan kelima isi media dipengaruhi oleh posisi ideologi dan mempertahankan status quo(Shoemaker \& Reese, 1996). Setiap media memiliki ideologi-ideologi yang dianut. Secara positif ideologi dipersepsikan sebagai suatu pandangan dunia yang menyatakan nilai-nilai kelompok sosial tertentu untuk membela dan memajukan kepentingankepentingan mereka, sedangkan secara negatif ideologi dapat dilihat sebagai suatu kesadaran palsu, yaitu suatu kebutuhan untuk melakukan penipuan dengan cara memutarbalikan pemahaman orang mengenai realitas sosial(Sobur, 2009). Perbedaan ideologis yang dimiliki setiap mediaakan melahirkan perbedaan konstruksi terhadap suatu peristiwa. Peristiwa yang sama bisa jadi akan dikonstruksi secara berbeda oleh media dikarenakan perbedaan ideologis yang mereka miliki.

Wartawan mempunyai pandangan dan konsepsi yang berbeda terhadap suatu peristiwa. Hal tersebut nampak dari bagaimana mereka mengkonstruksi peristiwa yang diwujudkan dalam teks berita.Berita dalam pandangan konstruksi social bukan merupakan peristiwa atau fakta dalam arti yang riil. Disini realitas bukan dioper begitu saja sebagai berita. Ia adalah produk interaksi antara wartawan dengan fakta. Dalam proses internalisasi,wartawan menceburkan dirinya untuk memaknai realitas. Konsepsi tentang fakta diekspresikan untuk melihat realitas.Hasildari berita adalah produk dari proses interaksi dan dialektika tersebut (Eriyanto, 2005). Istilah konstruksi social atas realitas (social construction of reality) menjadi terkenal ketika diperkenalkan oleh Peter L. Berger dan Thomas Luckmann. Kedua pemikir ini hanya meneruskan apa yang digagas oleh Giambitissta Vico yang kemudian banyak disebut sebagai cikal bakal konstruktivisme. Kalau kita mau menelaah, gagasan konstruktivisme ada jauh sebelum Berger yaitu ketika dalam aliran filsafat Socrates menemukan jiwa tubuh manusia, atau sejak Plato menemukan jiwa dalam tubuh manusia, atau sejak Plato menemukan akal budi serta ide(Bungin, 2001).

Pemberitaan tentang terorisme juga merupakan bagian yang tidak terlepas dari proses konstruksi. Hasil penelitian Mubarok, 2012 menunjukkan bahwa terminologi terorisme dalam pemberitaan media massa di Indonesia selalu dikaitkan dengan aksiaksi pemboman yang terjadi. Diksi terorisme lebih banyak dipilih daripada istilah lain seperti perbuatan anarkis, perbuatan melawan hokum (Mubarok, 2012). Terorisme adalah kasus special yang ditangani secara serius di berbagai Negara. Di Indonesia pemerintah membentuk satuan khusus Densus 88 Antiteror untuk menangani terorisme. Upaya tersebut menunjukkan keseriusan pemerintah untuk menghapus beragam ancaman terror yang terjadi di Indonesia.

Halyang tidak kalah penting dalamupaya menghapus terorisme di Indonesia adalah gerakan kontraterorisme yang menekankan aspek pencegahan daripada penindakan terror. Gerakan kontra terorisme dilakukan oleh berbagai negara dengan beragam cara. Di Indonesia dibentuk Badan Nasional Penanggulangan Terorisme (BNPT) yang melakukan proses represif maupun persuasif dalam menangani kasus terorisme. Lembaga kontra terorisme ini didirikan berdasarkan Peraturan Presiden Nomor 46 Tahun 2010 tentang Badan Nasional Penanggulangan Terorisme (BNPT). Upaya persuasif dalam gerakan kontraterorisme merupakan upaya kontra ideology radikal yang diwujudkan dalam beragam tindakan. Ceramah tokoh agama maupun masyarakat tentang deradikalikasi merupakan contoh upaya persuasive kontraterorisme. Pembentukan komunitas antiteror yang menyebarkan deradikalisi juga menjadi bagian dari upaya persuasive tersebut.

Media massa dengan kemampuanya untuk menyebarkan pesan secara luas 
dan massif tentunya menjadi pihak yang harus mengambil bagian dalam gerakan kontraterorisme tersebut. Media memiliki kemampuan propaganda, persuasif, dan melahirkan gerakan sosial melalui konstruksi pesan yang mereka lakukan. Melalui pemberitaan yang dikonstruksi sebagai pesan kontraterorisme media memegan peran penting dalam upaya deradikalisasi. Karena itu upaya untuk mendorong media massa mengkonstruksi pesan kontraterorisme harus terus dilakukan sebagai bagian dari upaya menghapus terorisme dari Indonesia.

Penelitian ini bertujuan untuk melihat bagaimana media massa di Indonesia melakukankonstruksipesankontraterorisme. Apakah media menempatkan upaya tersebut sebagai bagian serius dalam pemberitaan mereka. Bagaimana bentuk konstruksi pesan kontraterorisme yang telah dilakukan oleh media massa. Penelitian ini mengambil objek pemberitaan empat media besar di Indonesia. Pertama adalah Detik.com yang dipilih sebagai objek penelitian karena media online ini merupakan salah satu media online pertama yang ada di Indonesia dan diakses secara massif. Kedua Metrotvnews. comnews.com sebagai salah satu televise berita pertama di Indonesia. Ketiga adalah Kompas.com sebagai versi online dari harian Kompas yang selama ini dikenal dengan pemberitaan yang objektif. Keempat adalah Viva.co.id yang merupakan salah satu portal berita dan berjaringan dengan TV One.

\section{METODE}

Paradigmaberfungsisebagaiseperangkat keyakinan atau basic belief systems yang mengarahkan tindakan peneliti, berkaitan dengan prinsip-prinsip utama (pokok). Paradigma penelitian ini adalah paradigma konstruktivis yang berbeda dengan paradigma lain dalam hal epistimologi, ontology, aksiologi, dan methodolog (Denzin \& Lincoln, 2005). Analisis framing, sebagai teknik analisis dalam penelitian ini, termasuk ke dalam paradigm konstruktivisme. Penelitian ini menggunakan metode analisis framing Pan dan Kosicki. Dengan penelitian kualitatif ini penulis akan menggambarkan bagaimana konstruksi pembingkaian Media Dalam Pemberitaan Kontra Terorisme Di Indonesia. Objek dalam penelitian ini adalah pemberitaan Detik.com, Metrotvnews.com, Kompas.com dan Viva.co.id tentang kontra terorisme.

Model Pan dan Kosicki berasumsi bahwa setiap berita memiliki frame yang berfungsi sebagai pusat dari organisasi ide. Frame adalah suatu ide yang dihubungkan dengan elemen yang berbeda dalam teks berita seperti kutipan, latar informasi ,pemakaian kata atau kalimat tertentu ke dalam teks secara keseluruhan. Metode ini merupakan modifikasi dari dimensi operasional analisis wacana Van Dijk, yang mengoprasionalisasikan empat dimensi structural teks terita sebagai perangkat framing,yaitu: sintaksis,skrip,tematik dan teoritis (Prastya, 2016).

Menurut Pan Kosicki dalam (Sudibyo, 20o1) terdapat beberapa perbedaan utama dibanding analisis teks berita lainnya. Pertama, analisis framing tidak memandang teks sebagai rangsangan psikologis, tetapi lebih memandang sebagai sarana simbolik teratur yang akan berinteraksi dengan khalayak. Kedua,analisis framing tidak terikat oleh pendekatan strukturalis yang bebas isi terhadap semua wacana.Ketiga, validitas dan analisis framing tidak bersandar pada teks berita,namun prosedur sistematik dalam pengumpulan data.

Dalam pendekatan ini,framing di bagi menjadi 4 struktur besar. Penjabaran 4 struktur ini akan dijelaskan dengan menyarikan pembahasan Eriyanto (Eriyanto, 2005), pertama struktur sintaksis yang bisa diamati dari bagan berita yang meliputi cara wartawan menyusun berita. Struktur sintaksis memiliki perangkat: headline yang merupakan berita yang dijadikan topic utama oleh media dan lead (teras berita) merupakan paragraph pemgbuka dari sebuah berita yang biasanya mengandung kepentingan lebih tinggi. Struktur ini sangat bergantung pada ideology penulis terhadap peristiwa berupa: latar informasi,kutipan,su mber,pernyataan dan penutup. 
Kedua, struktur skrip yaitu cara wartawan mengisahkan fakta dengan melihat bagaimana strategi bertutur atau bercerita yang digunakan wartawan dalam mengemas berita. Struktur skrip memfokuskan perangkat framing pada kelengkapan ${ }_{5} \mathrm{~W}$ $+{ }_{1} \mathrm{H}$ yaitu what (apa), when (kapan), who (siapa), where (dimana), why (mengapa) dan how (bagaimana).

Ketiga, struktur tematik yaitu bagaimana seorang wartawan mengungkapkan suatu peristiwa dalam proposisi, kalimat yang membentuk teks secara keseluruhan. Struktur tematik mempunyai perangkat framing berupa detail, maksud dan hubungan kalimat, nominalisasi antar kalimat, koherensi, bentuk kalimat dan kata ganti.

Keempat, struktur retoris, bagaimana seorang wartawan menekankan arti tertentu atau dalam kata lain penggunaan kata,idiom, gambar dan grafik yang digunakan untuk member penekanan arti tertentu. Struktur retoris mempunyai perangkat framing diantaranya leksikon/pilihan kata yang merupakan penekanan terhadap sesuatu yang penting,grafis, metaphora dan pengandaian. Objek dalam penelitian ini adalah pemberitaan TV One, Metro TV, Kompas.com dan Detik.com tentang kontra terorisme. Dengan strategi yang lazim diterapkan pada penelitian framing seperti ini, diharapkan terlihat jelas bagaimana sebuah media melakukan framing terhadap sebuah peristiwa. Data utama yang diperoleh secara langsung pemberitaan TV One, Metro TV, Kompas.com dan Detik.com tentang kontra terorisme selama bulan JanuariDesember 2017.

Adapun perangkat framing yang digunakan sebagai pendekatan untuk menganalis data dalam penelitian ini sebagaimana disusun oleh Pan dan Kosicki, yang juga identifikasi sebagai perangkat wacana, dibagi menjadi empat struktur, yaitu : struktur sintaksis, struktur skrip, struktur matematik dan struktur retoris. Pendekatan tersebut digambarkan pada tabel berikut :
Tabel e.1

\section{Tabel kerangka framing Pan dan Kosicki}

\begin{tabular}{|c|c|c|}
\hline Struktur & Perangkat Framing & $\begin{array}{l}\text { Unit Yang } \\
\text { diamati }\end{array}$ \\
\hline $\begin{array}{l}\text { Sintaksis : } \\
\text { Cara wartawan } \\
\text { menyusun fakta }\end{array}$ & 1. Skema Berita & $\begin{array}{l}\text { Headline, } \\
\text { lead, latar } \\
\text { informasi, } \\
\text { sumber, } \\
\text { pernyataan, } \\
\text { penutup }\end{array}$ \\
\hline $\begin{array}{l}\text { Skrip : Cara } \\
\text { wartawan } \\
\text { mengisahkan } \\
\text { cerita }\end{array}$ & $\begin{array}{l}\text { 2. Kelangkapan } \\
\text { Berita }\end{array}$ & $5 \mathrm{~W}+1 \mathrm{H}$ \\
\hline $\begin{array}{l}\text { Matematik: } \\
\text { Cara wartawan } \\
\text { menulis fakta }\end{array}$ & $\begin{array}{ll}\text { 3. } & \text { Detail } \\
\text { 4. } & \text { Maksud } \\
& \text { Kalimat } \\
\text { 5. } & \text { Hubungan } \\
& \text { Antar Kalimat } \\
\text { 6. } & \text { Nominalisasi } \\
\text { 7. } & \text { Koherensi } \\
\text { 8. } & \text { Bentuk } \\
\text { 9. } & \text { Kalimat } \\
\text { 9ata Ganti } \\
\end{array}$ & $\begin{array}{l}\text { Paragraf, } \\
\text { proporsi }\end{array}$ \\
\hline $\begin{array}{l}\text { Retoris : Cara } \\
\text { wartawan } \\
\text { menekankan } \\
\text { fakta }\end{array}$ & $\begin{array}{l}\text { 10. Leksikon } \\
\text { 11. Gambar } \\
\text { 12. Metaphor } \\
\text { 13. Pengandaian }\end{array}$ & $\begin{array}{l}\text { Kata, idiom, } \\
\text { gambar/ } \\
\text { foto, grafis }\end{array}$ \\
\hline
\end{tabular}

Tabel : Tabel kerangka framing Pan dan Kosicki

\section{HASIL DAN PEMBAHASAN}

Upaya deradikalisasi membutuhkan keterlibatan berbagai pihak. Media bisa mengkonstruksi pesan kontraterorisme melalui pemberitaan yang dibuatnya. Pada bab ini akan dibahas framing dari Detik.com, Metrotvnews.comnews.com, Kompas.com dan Viva.co.id dalam pemberitaan kontra terorisme. Selanjutnya akan diuraikan kaitan konstruksi yang dikembangkan keempat media tersebut dengan teori yang relevan untuk memperkaya pembahasan.

\section{A. Framing Detik.com: hardnews tanpa upaya konstruksi pesan}

Detik.com merupakan salah satu portal berita yang banyak di akses. Kecepatan berita yang disajikan menjadi daya tarik utama portal ini. Detik.com saat ini tergabung dalam TransMedia Group . Jenis 
berita hardnews mendominasi pemberitaan tentang terorisme di media ini. Berita yang bersumber dari kepolisian baik dalam bentuk rilis berita maupun hasil wawancara mendominasi pemberitaan terorisme. Hal ini bisa dipahami mengingat sumber kepolisian adalah sumber terpercaya, cepat dan mudah diakses oleh jurnalis dibanding upaya untuk mendapatkan fakta di lapangan secara langsung. Berikut beberapa berita yang dikategorikan sebagai hardnews yang dikonstruksi oleh Detik.com.

Judul : Densus Kembali Tangkap

Terduga Teroris di Bima

Inti berita : Jakarta-Densus 88 Antiteror dan Polda Nusa Tenggara Barat (NTB) kembali menangkap seorang lagi terduga anggota kelompok teroris di Bima, NTB. Terduga teroris itu bernama Imam Munandar alias Nandar, yang diduga terlibat baku tembak dengan aparat di Gunung Mawu Rite, Ambalawi, Kecamatan Bima.

Analisis:

1. Struktur Sintaksis

Judul berita menggambarkan keberhasilan Densus 88 menangkap terduga teroris di BIMA, NTB. Penggunaan kata 'lagi' menunjukkan bahwa penangkapan teroris di Bima sudah dilakukan beberapa kali. Berita ini mengutip pernyataan sumber dari Kepolisian yang menyatakan bahwa terduga teroris yang ditangkap terlibat dalam beberapa kegiatan terror sebelumnya. Dia merupakan joki yang menjadi bagian dari tim Amir.

\section{Struktur skrip}

Struktur skrip memberikan penegasan bahwa Nandar (who) yang ditangkap sebagai terduga teroris memang melakukan kegiatan yang terkait dengan terorisme (why). Dia terlibat dalam baku tembak di gunung Mawu Rite, Nandar berperan sebagai joki bagi Amir yang menyerang polisi. Melalui skrip ini, pemberitaan ingin meyakinkan bahwa sosok yang ditangkap memang terduga teroris dengan bukti keterlibatan dalam aksi penyerangan polisi.

3. Struktur tematik

Tema utama pemberitaan ini adalah penangkapan terduga teroris yang terlibat dalam penyerangan polisi. Secara keseluruhan berita ini merupakan hasil wawancara dengan kepolisian yang diwakili oleh Karo Penmas Mabes Polri yang diuraikan dalam bentuk berita.

4. Struktur retoris

Dalam berita ini disebutkan secara khusus kata yang digunakan untuk menunjukkan seorang terduga teroris yaitu: peran sebagai Joki (sopir kendaraan), Nandar menjadi bagian dari kelompok teroris dengan peran sebagai sopir kendaraan bagi pelaku lain. Dia juga terlibat merencanakan Amaliyah (peledakan bom), kata Amaliyah secara spesifik digunakan setiap pemberitaan pemboman di Indonesia.

Lead berita menggambarkan dengan jelas aspek who, what dan why dalam unsur piramida pemberitaaan. Siapa yang melakukan terror, apa yang telah dilakukanya sehingga dia harus ditangkap melengkapi keseluruhan isi pemberitaan. Untuk menguatkan inti berita yang telah disarikan di lead, berita ini memberikan informasi penutup untuk mengkonstruksi pesan bahwa mereka yang ditangkap adalah pelau terror. Berikut petikan penutup berita: Penangkapan Nandar didahului dengan penangkapan 11 terduga teroris di wilayah Ambalawi, Kabupaten Bima, NTB sejak Senin (30/10) hingga Rabu (1/11). Dua di antaranya tewas dalam baku tembak dengan polisi. Sembilan terduga teroris yang tersisa kini diperiksa di Mako Brimob, Kelapa Dua, Depok, Jawa Barat untuk didalami keterangannya. Belum diketahui apakah Nandar akan dibawa ke Jakarta seperti yang lainnya

Penangkapan terduga teroris sebagaimana disarikan di lead berita merupakan aktifitas berkelanjutan dari kejadian sebelumnya. Dengan menggunakan narasumber tunggal berita ini belum memenuhi aspek cover both side sehingga penilaian validitias informasi tidak berimbang.

Berita kedua dari berjudul: "Polisi Tangkap Terduga Teroris di Bandung, Berperan Jadi Motivator". Berita ini juga termasuk dalam kategori hardnews. Sumber informasi berasal dari rilis kepolisian 
tentang keberhasilan Densus 88 menangkap terduga teroris di Bandung. Petika lead berita berikut ini menggambarkan dengan jelas keseluruhan isi berita.

"Cikopo - Tim Detasemen Khusus (Densus) 88 Antiteror kembali menangkap 1 orang terduga teroris di Bandung berinisial WT. Dia diduga terkait teror bom Kampung Melayu"

1. Struktur sintaksis

Judul berita menekankan keberhasilan kepolisian menangkap terduga teroris yang berperan sebagai motivator. Secara keseluruhan berita ini merupakan pernyataan kepolisian yang diuraikan dalam bentuk berita. Terduga teroris yang ditangkap adalah pimpinan yayasan yang berperan memotivasi terduga teroris lainnya. Kutipan pernyataan Humas Polda Jawa Barat menegaskan kembali berita penangkapan terduga teroris.

2. Struktur skrip

Berita ini menekankan pada aspek who (terduga teroris) yang ditangkap karena berperan memberikan motivasi. Aspek why (mengapa dia ditangkap) menegaskan bahwa penangkapan ini sudah didasari alas an yang kuat sehingga terduga teroris ini harus ditangkap.

3. Struktur tematik

Tema secara keseluruhan dari pemberitaan ini adalah keberhasilan kepolisian menangkap terduga teroris dengan peran yang jelas sebagai motivator.

4. Struktur retoris

Upaya peneguhan keterlibatan WH dalam kegiatan terorisme dilakukan dengan menggunakan pilihan kata; guru ngaji, memberikan tausyiah dan memberikan motivasi. Ketiga peran ini digunakan untuk menggambarkan sosok WH yang ditangkap.

Sebagaimana berita sebelumnya berita ini juga menekankan aspek who (terduga teroris) yang ditangkap karena peran yang nyata dalam mendukung kegiatan terorisme (why). Keterlibatan terduga teroris dalam memberikan motivasi kepada pelaku terror yang lain dijadikan sebagai alasan kenapa dia ditangkap. Kutipan pernyataan dari kepolisian berikut ini menguatkan hal tersebut " Dalam jaringan teror ini, WT berperan sebagai pemberi motivasi kepada 2 orang pelaku bom bunuh diri di kampung Melayu, yaitu INS dan AS".

Berita ketiga dari Detik.com berjudul: "Kapolri Diundang FBI untuk Mengajar Kontraterorisme". Berita ini mengutip pernyataan langsung dari Kapolri yang menyatakan diundang oleh FBI untuk memberikan materi kontraterorisme. Dalam berita ini Detik.com tidak secara langsung mengkonstruksi pesan kontraterorisme. Meski demikian isi pemberitaan yang mengutip materi tersebut nampak dari pernyataan Kapolri berikut ini: "materi pelajaran yang akan dibagikan kepada para agen FBI seputar tipe atau jenis jaringanjaringan teroris secara spesifik. Selain itu, akan mengajarkan langkah-langkah kontraterorisme, terutama dengan metode pendekatan preventif. Upaya preventif, seperti soft approach, lebih efektif mengatasi terorisme dibanding penindakan kejahatan teroris, seperti operasi militer".

1. Struktur sintaksis

Judul dan lead berita menggambarkan dengan jelas pernyataan Kapolri tentang undangan Amerika kepadanya untuk memberikan ceramah kontra terorisme. Hal ini menegaskan bahwa Indonesia dianggap memiliki kemampuan dan pengalaman yang memadai di bidang kontra terorisme sehingga bisa dibagikan pengalamanya kepada Amerika Serikat.

2. Struktur skrip

Berita ini menekankan pada aspek who (Kapolri) yang diundang ke Amerika Serikat untuk mengajarkan kontra terorisme (why).

3. Struktur tematik

Keseluruhan artikel merupakan pernyataan Kapolri tentang undangan Amerika Serikat kepadanya untuk mengajarkan kontra terorisme. Hal itu menjadi tema utama dari pemberitaan dan menjadi tema tunggal karena merupakan kutipan pernyataan sumber yang diuraikan menjadi berita.

4. Struktur retoris

Pendekatan soft approach dalam ceramah kontra terorismeyang akan dilakukan Kapolri di Amerika Serikat sekaligus menegaskan bahwa pendekatan tersebut yang digunakan 
untuk menangkal terorisme di Indonesia.

Dalam berita ini dijelaskan tentang tindakan kontraterorisme yang dimaksud. Ada langkah-langkah kontraterorisme yang lebih efektif daripada penindakan kejahatan terorisme melalui operasi militer. Langkah tersebut menggunakan pendekatan soft approach sebagai bagian dari upaya preventif. Pendekatan ini dimulai dari pengenalan jenis jaringan teroris secara spesifik yang kemudian diikuti dengan pendekatan preventif yang tepat.

Detik.com tidak menempuh upaya untuk mengkonstruksi pesan secara khusus terhadap kegiatan kontraterorisme. Pemberitaan media ini menekankan pada one way source dengan mengutamakan sumber dari kepolisian. Detik.com tidak berusaha untuk menempuh jalan lain dalam memperoleh informasi tambahan sehingga dihasilkan sebuah pemberitaan yang komprehensif. Konstruksi pesan kontraterorisme tidak nampak dalam pemberitaan media ini. Dalam berita berjudul "'Kapolri Diundang FBI untuk Mengajar Kontraterorisme" ada muatan kegiatan kontraterorisme yang dimaksud oleh kepolisian. Meski demikian detik.com tidak berusaha untuk memngembangkan konstruksi melalui pemberitaanpemberitaan lainnya sehingga terbangun sebuah konstruksi kontraterorisme. Mereka mencukupkan mengutip narasumber dari satu pihak dan menuliskan berita begitu saja. Upaya untuk menggali dan mengembangkan konsep-konsep kontraterorisme yang telah disebuatkan dalam pemberitaan tidak dilakukan oleh media ini.

\section{B. Framing Metrotvnews.comnews.com: testimoni dan upaya deradikalisasi}

Pemberitaan Metro TV tentang kontraterorisme bersumber pada testimoni mantan narapidana terorisme yang telah bertaubat. Melalui narasumber yang berasal dari pelaku terorisme media ini ingin menunjukkan bahwa apa yang telah dipahami dan dilakukan oleh para teroris tersebut adalah sebuah kesalahan. Sumber pelaku yang telah bertaubat diharapakan memberikan gambaran yang utuh dan nyata tentang kegiatan terrorisme di Indonesia dan bagaimana pemahaman yang salah memunculkan beragam aksi terror.

Berikut adalah berita yang dilansir Metro TV pada 22 Desember 2017 09:12 wib. Berita dengan Judul "Dari Balik Penjara Gino Belajar Mengkafirkan Orang" menjadi awal dari rangkaian pengungkapan testimoni mantan narapidana terorisme bernama $\mathrm{Abu}$ Gino.

\section{Struktur sintaksis}

Lead berita yang menyatakan "Hukuman penjara untuk membuat pelaku kejahatan jera agaknya tak selalu demikian. Abu Gino, mantan pengikut kelompok radikal yang pernah menjadi terpidana menyaksikan sendiri bahwa di balik jeruji besi seseorang yang diharapkan bisa bertaubat justru semakin jahat" mengungkapkan dengan jelas bagaimana isi berita. Kutipan tunggal yang digunakan dalam berita ini menunjukkan bahwa secara keseluruhan berita ini adalah hasil kesaksian seorang mantan teroris tentang doktrinasi radikal yang terjadi dibalik penjara.

2. Struktur skrip

Berita ini menekankan pada aspek who (Abu Gino) sebagai sumber berita tunggal. Pengalamannya menerima doktrinasi radikal di dalam penjara (what) menjadi sumber pemberitaan utama.

3. Struktur tematik

Tema utama pemberitaan adalah kaitan antara penjara dengan radikalisme. Berdasar pengalaman Abu Gino berita ini ingin menunjukkan bahwa narapidana terorisme justru semakin keras karena mendapatkan doktrinasi terorisme di dalam penjara.

4. Struktur retoris

Tiga kata utama yang digunakan untuk menggambarkan proses doktrinasi di dalam penjara adalah: takfiri (mengkafirkan orang yang tidak sepaham), kaderisasi rekrutmen pelaku terror yang dilakukan dari dalam penjara, dan amaliyah yaitu praktek terror yang bisa berupa pengeboman atau penyerangan aparat kepolisian.

Lead berita "Hukuman penjara untuk membuat pelaku kejahatan jera agaknya tak 
selalu demikian. Abu Gino, mantan pengikut kelompok radikal yang pernah menjadi terpidana menyaksikan sendiri bahwa di balik jeruji besi seseorang yang diharapkan bisa bertaubat justru semakin jahat". Melalui berita ini Metro TV ingin menunjukkan bahwa penjara justru menjadi tempat subur menyemai benih terorisme. Para pelaku terror yang ditangkap dan dimasukkan ke dalam penjara bertemu dengan pelaku terror lainnya. Mereka belajar satu sama lain. Mereka juga bertukar pengetahuan, melakukan kaderisasi bahkan merencanakan kegiatan terror dari dalam penjara. Melalui pemberitaan ini jelas menunjukkan bahwa perlu adanya evaluasi dalam sistem tahanan di Indonesia agar penjara tidak digunakan untuk menyemai kejahatan baru.

Untuk memperkuat lead berita diberikan latar informasi "Penjara bisa digunakansebagaitempatuntukmenyebarkan paham radikal kepada narapidana lain". Seorang narapidana terorisme yang tadinya pemahamanya masih sempit akan semakin luas karena dia bergaul dengan teroris lainya. Keyakinanya semakin mantap dan dia dikader untuk masuk dalam jaringan teroris yang lebih luas. Dari dalam penjara dia belajar berbagai hal untuk persiapan melakukan aksi terror. Mereka belajar taktik perang bahkan belajar cara membuat bom, mereka berbaiat untuk melakukan terror. Paragraf penutup dari berita ini menyajikan kaitan antara terorisme di Indonesia dengan negara lain. Artikel tersebut ditutup dengan paragraph penutup "Kegiatan terorisme di Indonesia terkait dengan aktivitas di negara lain contohnya Suriah". Dalam kegiatan kontraterorisme harus diikuti pemahaman beragam aksi terror di Negara lain. Pemahaman ini penting untuk mengetahui jaringan teroris, pola aksi dan apa kaitan aksi di luar negeri dengan aksi terror di Indonesia.

Dalam berita tersebut bisa disarikan hal-hal penting dalam upaya tindakan kontraterorisme. Pertama, perlu adanya pembaharuan dalam penanganan para terduga teroris terutama di dalam penjara. Ketika penjara justru digunakan untuk mengembangkan aksi terror, maka tujuan pemasyarakan tidak tercapai. Upaya kontraterorisme harus melibatkan upaya untuk memperbaiki lembaga pemasyarakatan. Kedua, kaitan antara terorisme di dalam negeri dengan luar negeri. Media yang menyiarkan berbagai aksi terror di luar negeri juga harus berfikir bahwa apa yang mereka beritakan bisa menginspirasi pelaku terror di Indonesia. Kedua hal tersebut menjadi pesan utama dalam pemberitaan Metrotvnews.com sebagaimana telah diungkapkan sebelumnya.

Berita kedua Metrotvnews.com berjudul "Cerita Gino, Terpapar Ajaran Radikal di Usia Muda". Berita ini merupakan kelanjutan berita yang pertama tentang testimony mantan pelaku terror yang terpapar ajaran terorisme sejak usia muda. Generasi muda yang memiliki rasa ingin tahu tinggi dan kemauan keras serta sifat terbuka dianggap rentan untuk mendapatkan terpaan terorisme. Berikut adalah lead berita yang menggambarkan cerita mantan pelaku terror terkena ajaran terorisme di usia muda. Analisis:

1. Struktur sintaksis

Lead berita menggambarkan upaya rekrutmen generasi muda untuk melakukan terror. Dalam lead yang berbunyi "Sudah bukan rahasia, jaringan kelompok radikal dan terorisme selalu menyasar para penerus generasi bangsa. Anak muda, entah itu remaja maupun dewasa adalah target empuk untuk ditarik agar ikut bergabung dalam kelompok radikal" menunjukkan dengan jelas inti berita tersebut.

2. Struktur skrip

Berita ini merupakan testimony mantan pelaku terror yang mendapatkan ajaran radikal semenjak usia muda. Who (Abu Gino) membagikan kisahnya terlibat dalam ajaran terorisme semenjak usia muda.

3. Struktur tematik

Tema utama tentang terpaan ajaran radikal pada generasi muda ditunjukkan dari kesaksian mantan narapidana terorisme. Tema ini menjadi tema tunggal yang dikuatkan dengan kronologis mulai dari proses mengenal ajaran radikal sampai dengan melakukan aksi terror. 


\section{Struktur retoris}

Pilihan kata yang digunakan adalah amaliyah, jihad, kaderisasi dan kajian eksklusif. Hal ini ingin menunjukkan kaitan antara proses (mengikuti kajian eksklusif) denan kaderisasi dan hasilnya (amaliyah).

Lead berita "Sudah bukan rahasia, jaringan kelompok radikal dan terorisme selalu menyasar para penerus generasi bangsa. Anak muda, entah itu remaja maupun dewasa adalah target empuk untuk ditarik agar ikut bergabung dalam kelompok radikal.". Gino mengakui bahwa ikut serta dalam kelompok jaringan teroris bukan karena doktrin melainkan keyakinan bahwa ajaran untuk berjihad adalah benar. Keyakinan tersebut membuat Ia gelap mata dan melupakan segalanya, bahkan tentang fakta bahwa jihad semacam itu bertentangan dengan agama".

Petikanlead tersebutmenggambarkan tiga konstruksi utama dalam konsep kontraterorisme. Pertama, generasi muda adalah sasaran utama proses doktrinasi terorisme. Karena itu perlu dikembangkan pesan-pesan kontraterorisme yang bisa menjangkau generasi muda bangsa. Kedua, pemahaman tentang konsep jihad yang keliru dikalangan sebagian umat Islam sehingga berujung pada manifestasi ajaran yang keliru. Karena itu konsep kontraterorisme harus mengadopsi pemahaman jihad yang benar sehingga bisa diturunkan dalam pesan-pesan yang mudah dipahami, kontekstual dan relevan dengan generasi muda saat ini. Ketiga, pemahaman jihad yang keliru menjadikan penganutnya gelap mata dan menghalalkan segala cara. Karena itu menghadapi kondisi semacam ini diperlukan pesan-pesan konsruktif yang mampu dipahami dan diaplikasikan oleh generasi muda.

Upaya media ini menghadirkan pesan-pesan kontraterorisme melalui mantan terpidana terorisme menunjukkan terobosan yang berbeda dibanding media lainnya. Metrotvnews.com mencoba mengkonstruksi pesan yang berbeda dengan menghadirkan sumber lain berupa testimony manta terpidana terorisme.
Dibanding sumber-sumber resmi aparatur negara yang lebih banyak memberitakan aksi penangkapan teroris, testimony ini lebih mengena dikalangan generasi muda. Media ini berusaha menunjukkan sisi-sisi lain dari aspek penanganan terorisme termasuk manajemen lembaga pemasyarakatan yang harus dibenahi karena justru menjadi sarang doktrinasi radikalisme.

\section{Framing Kompas.com : kontraterorisme dari sumber utama}

Salah satu upaya untuk mengkonstruksi pesan terorisme nampak pada berita yang dimuat tanggal 27 September 2017 berjudul "BNPT Rekrut Bloger dan Netizen untuk Melawan Kelompok Teroris".

Analisis:

1. Struktur sintaksis

Lead berita "Kepala Badan Nasional Penanggulangan Terorisme ( BNPT) Komjen Pol Suhardi Alius mengungkapkan bahwa pihaknya telah merekrut bloger dan netizen untuk dilibatkan dalam upaya meredam penyebaran paham radikal melalui internet" menggambarkan inti berita secara keseluruhan.

\section{Struktur skrip}

Kutipan tunggal pernyataan dari narasumber utama (who) menunjukkan aspek kredibilitas narasumber untuk menunjukkan kredibilitas fakta berita (what). Aspek ini dikaitkan dengan aspek why " rekrutmen ditujukan untuk Menangkal propaganda terorisme di dunia maya”.

3. Struktur tematik

Tema tunggal yaitu upaya BNPT melakukan kontraterorisme di dunia maya dengan merekrut netizen dan blogger untuk mengembangkan konten dan propaganda kontraterorisme.

4. Struktur retoris

Pilihan kata yang digunakan: netizen, blogger, kegiatan kontraterorisme dan propaganda kontraterorisme.

Berita ini menggambarkan urgensi peran bloger dan netizen dalam upaya deradikalisasi. Dunia maya dianggap sebagai salah satu sumber utama penyebaran paham radikal sekaligus dijadikan sebagai tempat 
rekrutmen calon pelaku terror. Media sosial penuh dengan konten radikalisme dan terorisme sehingga dibutuhkan upaya serius untuk menangkal di dunia kasat mata ini. Berikut adalah lead berita tersebut "Kepala Badan Nasional Penanggulangan Terorisme ( BNPT) Komjen Pol Suhardi Alius mengungkapkan bahwa pihaknya telah merekrut bloger dan netizen untuk dilibatkan dalam upaya meredam penyebaran paham radikal melalui internet". Keterlibatan bloger dan netizen dianggap krusial untuk meredam penyebaran paham radikal di dunia maya. Karena itu BNPT menjadikan program ini sebagai bagian dari langkah kontra terorisme. Konstruksiyang dikembangkan oleh Kompas. com menunjukkan pentingnya peran aktif di dunia dalam progam kontraterorisme.

Berikut lanjutan lead berita "Hal itu dilakukan sebagai bentuk kontrapropaganda paham radikal yang disebarkan oleh kelompok terorisme di media sosial". Pesan kontraterorisme dimaknai sebagai bentuk kontra-propaganda yang dilakukan para pelaku terror. Pendekatan ini masih menafikan bentuk penyebaran ideology radikal melalui cara-cara yang lain misalnya doktrinasi antar individu yang sering dilakukan pelaku terror. Konstruksi pemberitaan Kompas.com dengan mengutip sumber-sumber dari Kepolisian ditujukan untuk menjaga kredibilitas dan menempatkan pada posisi yang tidak memihak kelompok manapun. Beragam argument disampaikan oleh organisasi Islam tentang upaya deradikalisasi, dan media ini memposisikan diri untuk tidak memihak kepada salah satu kelompok tersebut. Rekrutmen bloger dan netizen merupakan bagian dari upaya deradikalisasi disamping pendekatan normative lainya.

Sebagaimana disebutkan dalam penutup berita, upaya yang dilakukan BNPT dalam menanggulangi radikalisme juga menggunakan pendekatan normative berupa pembentukan organisasi anti radikalisme. Berikut petikan berita tersebut. "Media sosial seperti Facebook, Twitter, Instagram, dan Youtube pun digunakan sebagai sarana kontra-propaganda. Selain itu, dalam melakukan kontra-radikalisasi, BNPT juga membentuk Forum Koordinasi Pencegahan Terorisme (FKPT) di 32 provinsi”.

Konstruksi pesan kontraterosimeyang dilakukan oleh Kompas.com menekankan pentingnya keterlibatan blogger dan netizen. Perkembangan sosial media demikian pesat dan bisa dimanfaatkan untuk beragam tujuan. Organisasi terror seperti ISIS juga memanfaatkan sosial media untuk menyebarkan paham, melakukan cuci otak, melakukan rekkrutmen bahkan memberi perintah untuk melakukan aksi terror. Generasi muda saat ini aktif di berbagai sosial media dan mereka merupakan sasaran empuk dari penyebaran ideology radikal. Karena itu upaya kontraterorisme di media sosial harus mendapatkan perhatian yang serius. Pesan ini yang dikembangkan oleh Kompas.com dengan merujuk pada kebijakan BNPT merekrut blogger dan netizen dalam rangka kontraterorisme.

\section{Framing Viva.co.id : Terorisme terstruktur Lebih Mudah Diatasi}

Dalam berita yang dimuat pada tanggal 11 juli 2017 berjudul: "Polisi Mengaku Sulit Deteksi Gerakan Teroris Individual”. Analisis:

1. Struktur sintaksis

Lead yang berbunyi "Kepolisian mengakui kesulitan melacak dan mendeteksi gerakan pelaku teror individual alias lone wolf. Aksi teror mereka yang tak terorganisir ini cenderung tak menentu, sehingga sulit diprediksi", merupakan upaya untuk menunjukkan bahwa pola serangan teroris ada yang terstruktur da nada yang tidak. Serangan tidak terstruktur lebih sulit untuk dideteksi

\section{Struktur skrip}

Unsur utama berita terletak pada how yang menjelaskan pola-pola serangan teroris baik yang terstruktur maupun bergerak sendiri.

3. Struktur tematik

Tema utama pemberitaan menunjukkan penjelasan pola-pola serangan teroris baik yang terstruktur maupun tidak.

4. Struktur retoris

Pilihan kata 'lone wolf” menunjukkan upaya 
yang tidak terstruktur dalam menyerangan dan berberak berdasar kemauan sendiri. Persamaan visi yang menunjukkan mengapa mereka mau melakukan gerakan tersebut.

Viva.co.id ingin menunjukkan bahwa kepolisian memiliki kemampuan untuk mengatasi terorisme yang terorganisir. Sementara teroris yang bergerak sendirian justru sulit untuk dideteksi. Lead berita yang berbunyi "Kepolisian mengakui kesulitan melacak dan mendeteksi gerakan pelaku teror individual alias lone wolf. Aksi teror mereka yang tak terorganisir ini cenderung tak menentu, sehingga sulit diprediksi" menunjukkan dengan jelas bagaimana kesulitan kepolisian menangani teroris tunggal yang tidak terorganisir.

Petikan tubuh berita berikut ini menggambarkan maksud dari kesulitan yang dihadapi kepolisian. "'Lone wolf ini bergerak sendiri, tujuannya tidak tentu. Beda dengan mereka yang masuk ke dalam satu jaringan yang bisa kita maping oleh tim Densus," ujar Kepala Bidang Humas Polda Jawa Barat, Kombes Pol Yusri Yunus, Selasa 11 Juli 2017". Viva.co.id tidak melakukan konstruksi pesan kontraterorisme dalam pemberitaan ini. Mereka ingin menunjukkan bahwa penanganan terorisme yang dijalankan oleh kepolisian selama ini sudah tepat. Kesulitan ketika menghadapi serangan tunggal menjadi sebuah pengecualian dari kerja kontraterorisme secara umum.

Berita ini juga menunjukkan bahwa kemampuan Kepolisian untuk mengatasi gerakan terror di Indonesia membutuhkan dukungan dari berbagai pihak. Teroris yang bergerak sendirian sulit untuk dideteksi sehingga membutuhkan bantuan dari segenap masyarakat untuk mengungkap aksi tersebut. Kepolisian memiliki kemampuan untuk mendeteksi teorisme yang terorganisir namun kesulitan untuk menghadapi teroris tunggal.

\section{E. Empat Media Minim Konstruksi Kontraterorisme}

Ancaman insurgensi, termasuk yang menggunakan cara utama terorisme, di Indonesia bersumber dari dua situasi, eksternal dan internal. Lingkungan eksternal terutama dikarenakan faktor globalisasi dan situasi dunia yang berubah unipolar. Globalisasi telah mempermudah transportasi dan komunikasi global sehingga nilai dan norma suatu kebudayaan dapat tersebar dan mempengaruhi kebudayaan lainnya (Karnavian, 2013).

Serangan teroris selalu dramatis dan mengandung sisi kemanusiaan, apalagi jika jatuh korban. Selain itu terorisme hampir selalu memiliki pengaruh (impact) internasional. Untuk kasus di Indonesia, misalnya, serangan teroris ditujukan kepada komunitas internasional seperti kedutaan, properti milik asing, atau warga negara asing. Dengan demikian dapat dipastikan terorisme memenuhi syarat-syarat bagi berita utama dalam sebuah media. Belum lagi aspek kekerasan dan darah, kerusakan, tragedi, ketakutan, heroisme dan hal-hal lain yang membuat peristiwa tersebut semakin atraktif untuk diberitakan.

Selanjutnya kompetisi antar media dan kecepatan dalam pemberitaan juga memberikan kontribusi bagaimana media menggunakan terorisme. Tidak bisa kita elakan lagi, setelah liberalisasi media massa, kompetisi merupakan hal yang sangat fundamental. Dalam hubungannnya dengan televisi dan pemberitaan maka setiap stasiun televisi akan berlomba bukan hanya mencari berita dengan sisi yang paling atraktif akan tetapi juga menjadi yang pertama menayangkannya.

Keberhasilan pengungkapan kasus Bom Bali 1 dan jaringan teror JI telah membuat Polri dipercaya untuk menjalankan peran "keamanan besar"nya yang selama ini diragukan banyak kalangan apakah akan dapat diperankan oleh Polri dengan berhasil. Sadar atau tidak sadar, pemerintah telah mulai mendapatkan format yang dirasakan pas dengan situasi aktual era reformasi dalam menanggulangi gerakan insurgensi. Pemerintah menekankan strategi penegakan hukum dengan metode "due process of law" dimana para pelaku teror, yang sebenarnya insurgen, diproses hukum dan diajukan ke pengadilan dalam sidang terbuka dan 
menampilkan "game" adu bukti. Strategi ini dirasakan cocok dengan lingkungan saat ini yang demokratis dan menekankan perlindungan HAM. Sekali lagi, sadar atau tidak, strategi ini telah membawa dampak positif dalam prinsip kontra-insurgensi para teoretis strategis, yang menekankan pentingnya memisahkan insurgen dari masyarakat/populasi sehingga insurgengagal merebut dukungan populasi(Karnavian, 2013).

Keempat media selama tahun 2017 tidak secara khusus melakukan upaya konstruksi pesan kontraterorisme. Catatan dari pemberitaan yang dimuat keempat media tersebut terletak pada satu aspek persamaan yaitu mengutip sumber tunggal dari aparatur resmi Negara. Kepolisian menjadi narasumber terbanyak dalam pemberitaan. Hal ini bisa dipahami karena kepolisian melalui Densus 88 merupakan actor utama yang diberikan kewenangan oleh Negara untuk menangani terorisme. Kedua, sumber dari BNPT menduduki porsi cukup banyak setelah kepolisian. BNPT adalah sebuah badan yang ditujukan untuk mengembangkan dan melaksanakan system penanggulangan terorisme melalui pendekatan persuasive.

\section{SIMPULAN}

Keempat media selama tahun 2017 tidak secara khusus melakukan upaya konstruksi pesan kontraterorisme. Catatan dari pemberitaan yang dimuat keempat media tersebut terletak pada satu aspek persamaan yaitu mengutip sumber tunggal dari aparatur resmi Negara. Kepolisian menjadi narasumber terbanyak dalam pemberitaan. Hal ini bisa dipahami karena kepolisian melalui Densus 88 merupakan actor utama yang diberikan kewenangan oleh Negara untuk menangani terorisme. Kedua, sumber dari BNPT menduduki porsi cukup banyak setelah kepolisian. BNPT adalah sebuah badan yang ditujukan untuk mengembangkan dan melaksanakan system penanggulangan terorisme melalui pendekatan persuasif.

Framing Detik.com menekankan pemberitaan hardnews dalam pemberitaan terorisme selama tahun 2017. Metrotvnews. com mengedepankan testimony pemberitaan dengan narasumber manta pelaku terror sebagai upaya kontraterorisme. Kompas. com mengedepankan sumber resmi dari kepolisian dan BNPT dalam mengkonstruksi pesan kontraterosime. Viva.co.id memuji kinerja kepolisian dan menekankan aspek lone wolf (teroris tunggal) sebagai pengecualian penangan terorisme yang terstruktur. 


\section{DAFTAR PUSTAKA}

Bungin, B. (2001). Metodologi Penelitian Kualitatif. Jakarta: Rajawali Press.

Denzin, N. K., \& Lincoln, Y. S. (2005). Handbook of Qualitative Research. London: Sage Publication.

Eriyanto. (2005). Analisis Framing. Yogyakarta: PT LkiS Pelangi Aksara.

Karnavian, T. (2013). Strategi Penanganan Insurgensi Dan Terorisme Indonesia. Srigunting.

Littlejohn, S. W. (2008). Theories of Human Communication 9th Edition (9th ed.). Wadsworth: Belmont CA.

Mubarok. (2012). Stigmatisasi Pemberitaan Terorisme di Media Massa. Interaksi MIKOM Undip, 1(1), 34-45.

Prastya, N. M. (2016). ANALISIS FRAMING DALAM RISET PUBLIC RELATIONS Narayana. Informasi UNY, 46(2), 193204.

Shoemaker, P., \& Reese, S. D. (1996). Mediating the Message: Theories of Influences on Mass Media: 2nd edition (2nd ed.). Newyork: Longman.

Sobur, A. (2009). Analisis Teks Media. Bandung: PT. Remaja Rosdakarya.

Sudibyo, A. (2001). Politik Media dan Pertarungan Wacana. Yogyakarta: PT LkiS Pelangi Aksara. 